\title{
Black Aesthetics:
}

\section{Upsetting, Undoing, and Uncanonizing the Arts Therapies}

\author{
Marisol Norris ${ }^{1 *}$, Britton Williams ${ }^{2}$, Leah Gipson ${ }^{3}$ \\ 1 Creative Arts Therapies \& Counseling, Drexel University, USA \\ 2 Drama Therapy, New York University, USA \\ 3 Art Therapy \& Counseling, School of the Art Institute of Chicago, USA \\ *marisol.s.norris@gmail.com
}

Published: 20 April 2021

As three Black American women guest editors of this special issue, we came together out of the continued need to address the multiple ways Black spaces and Black imaginations have cultivated the ground for the arts therapies. We recognized the need to delineate how the social stratification of Blackness allows for thematic construction of expression, implicating an expansive conception of Black aesthetics within disciplinary practices. Dually, we recognized the need to address contemporary discussions about the place and significance of Black peoples in the "field" (Thomas \& Norris, 2021). While Black aesthetics has been a focus of our individual and collective work since our earliest experiences in arts therapies classrooms, our observations have revealed that when Black arts therapists focus on Blackness within pedagogy, practice, and research, their work is marginalized, contested, or subjected to oversight or surveillance (Norris, 2020a; Stepney, 2019). Although professional practices of surveilling Blackness in the field have appeared more subtly and at times to advance multiculturalism, this type of anti-Blackness has had a significant impact on theory, practice, and the development of Black aesthetics discourse that informs the whole of the arts therapies professions. This special issue is carried forward by a Black cultural overtone of protest against anti-Blackness. Attending to Black voices is a necessary, sustaining work of politically mediating Blackness across disciplinary boundaries-what it means to live in our skins and in arts therapies spaces and what it means to transgress dominant professional practice. We conceived this issue to center experiences of Black arts therapies communities and the emerging dialogue on Black aesthetics in the arts therapies professions.

Black aesthetics is broadly defined as the processes and relational meaning-making of peoples racially positioned as Black. It centers the breadth of Black experiences within a world stratified by racial orders. While Black aesthetics include a wide collection of philosophical arguments about Black art and lifeworlds, contemporary scholars have delineated its trajectory as a political project within two periods (Taylor, 2016). Taylor (2016) noted that the first period marks a time when Africans and non-Africans sought to create and explore beauty and meaning within new distinctions of race, sourced from the first conceptualization of Blackness juxtaposed with whiteness. The second period arose when Black artists, scholars, critics, and other thinkers began to 
systematically approach their expressive practices from the lens of "modern race-thinking" (Taylor, 2016, p. 12). As such, Black aesthetics engendered the broad practice of "art, criticism, or analysis to explore the role that expressive objects and practices play in creating and maintaining Black life-worlds" (Taylor, 2016, p. 6). Yet, Blackness has been historically critiqued, maligned, fetishized, or otherwise condemned within dominant western aesthetic discourse (Bewaji, 2012; DuBois Shaw, 2004; Moten, 2003; Welsh-Asante, 1994). Black aesthetics is a response to the necessity of dislodging Black or essentially African subjects from the white aesthetic gaze and the movement of Black people from objectivity into the realm of subjectivity.

This issue joins Black power, Black radical, Black freedom, Black consciousness, and Black arts movements that proposed a "radical reordering of western cultural aesthetics" (Neal, 1968, p.29). At the helm of centuries of Black being, doing, reflection, analysis, and struggle, this issue disrupts dominant discourse that historically negates African and African diasporic peoples' humanity and generativity. We contend with widely preserved Hegelian assumptions that not only deem Black people as primitive but void of a human spirit (Crawley, 2017). The values of Black aesthetics in relation to Black radical freedom struggles serve as a political and artistic pursuit committed to Black self-determination and collective liberation. These values also resist the Black cis-hetero-patriarchal gaze that would erase Black women and gender and sexual minorities out of the aesthetic discourse (Avilez, 2017).

\section{A Critique of the White Gaze in the Arts Therapies}

Centering Black voices and experiences is particularly important in this special issue because the white gaze permeates the creative arts therapies. The white gaze interprets Black people "through the lens of whiteness" and "distorts perceptions of people who deviate from whiteness" (Rabelo et al., 2020, p. 1). The creative arts therapies have a long history of white authors writing about Black clients without Black people. Foundational assumptions and assessments about working with Black peoples and within Black communities are framed through the white gaze. This framework upholds a colonial positioning. Black knowledge and practices from across the African diaspora have been largely dismissed within the creative arts therapies and also abstracted and reframed through white lenses. This special issue actively and intentionally upsets the white gaze; in doing so, we follow Toni Morrison's commitment herein to unsettling the white gaze as dominant.

Decentering the white gaze is both a work of disrupting and undoing patterns of erasure and co-optation in the creative arts therapies across multiple contexts. The white gaze is "hegemonic, historically grounded in material relations of white power" (Yancy, 2013, section III, para. 4); it operates as a violent force that seeks to strip Black people from themselves and render us un-human. Seen historically from European enslavers deeming African people property to the present ease in which Black people are murdered by the state, punished in schools, misdiagnosed and maltreated in hospitals, and (...). The white gaze is chronically and persistently harmful to Black peoples. Coates (2015) said, "In America, it is traditional to destroy the Black body-it is heritage" (p. 103). This issue on Black aesthetics seeks to interrupt practices in the creative arts therapies that perpetuate a global legacy of destroying Black life.

\section{Thematic Frames in the Black Aesthetics Special Issue}

The call for papers for the Black aesthetics special issue was announced in November 2019, barely ahead of the first year of the COVID-19 pandemic. We have framed the writings in this volume into three ethics categories: care, authorship, and ownership. These categories, which are already strongly connected to Black experiences of place and time, are layered with meaning in the wake of COVID-19. The Center for Disease Control (2021b) reported that Native American, Black, and Latinx people are two to three times more likely than white non-Hispanic people in the US to be hospitalized or die from COVID-19. Within the last year, over 500,000 people have died from 
COVID-19 in the US; Black people are overrepresented at 14.7 percent of the overall number of deaths (Center for Disease Control, 2021a). What does an ethics of care look like in the context of compounding oppressions and a pandemic? Weeks into the first wave of the coronavirus in the US, we discussed the potential impacts of the pandemic on the contributing authors. Knowing the disproportionate impacts of wider crises on Black communities with whom authors identified, we advocated for an extension on the timeline to release the issue. Although we were initially met with "understanding," we were asked to consider a brief extension of one month, based on the attempt to "think logically" about the traditional number of journal issues in a year and the key role of special issues in reaching this objective number. After Ahmaud Arbery, Sean Reed, and Breonna Taylor were murdered by vigilantes and police, we again advocated, this time for a more realistic extension, and explicitly outlined in our argument why an issue on Black aesthetics should warrant consideration of how racial inequity during a pandemic might have implications for Black authors. A decision was made to grant the deadline extension for the issue to be released March 2021. George Floyd was murdered 12 days after this decision, and a new resurgence of a racial justice movement began. We recall this negotiated exchange between editors and guest editors as a commentary on how the arts therapies must be reoriented in relation to Black life by examining how decisions are made within systems that shape the field (Gipson et al., 2020). Social positioning motivates ideas and institutional practices that inform decisions, including a felt sense of "understanding" and higher appeals to "logic." Each of these modes of interpretation are subject to a set of ethics that deal with time and place in a social world.

Between African peoples, articulations of place form part of Black aesthetics traditions, reflecting the positionality of Black personhood. Therefore, Black aesthetics must attend to an intersectionality of gender, sexuality, class, disability, religion, and citizenship of Black peoples. As such, Black aesthetics amplifies, describes, and illuminates the non-monolithic lifeworlds created by and assumed by Black peoples. Black aesthetics invites critical analysis of place within various modes of art and literary expression. The categories we put forward upset a dominant white gaze and describe how each author approaches questions of power. Although our call for papers on Black aesthetics did not specify a call to Black arts therapists and artists, the editors and authors in the special issue identify as African and/or Black within the diaspora. Therefore, we note the significance of Black authorship in response to the many conversations about Black people in mental health and human services that happen without us. At the same time, the arts therapies have neither precedent nor commitment to name when journal volumes and other academic publications frequently include only white authors and editors. Recognizing our positions as guest editors in the United States, we also note the limitations of this issue in engaging international voices needed to critique US dominance in the arts therapies, which is a racial justice issue.

In the title of our editorial upsetting, undoing, and uncanonizing engages a Black temporality to negate a professional passivity toward racism in the field. Black aesthetics arrests and rebukes the first fallacious meeting of Africanness and unfreedom. We open the special issue with a cover image, a photograph by Scheherazade Tillet, "Anaya, Sixteen, Poet," from the series My Family Chair, in homage to Black arts therapists, artists, activists, scholars, and ordinary people who have pictured Black subjectivities through a lens of politicized love. Confronting the violence of the white gaze in the arts therapies, which is linked to a broader anti-Black acceptance of unnecessary pain and death, we "wanted to make present the someone that [a young Black child's] eyes look out to ... to stay in the wake to sound an ordinary note of care" (Sharpe, 2016, p. 132). Using multiple articulations of moment and place, the authors in this issue are resisting colonial possession (vis-a-vis the gaze, discourse, theft, co-optation, and domination) over one's body, knowledge, experience, place, and possibilities of care. 


\section{Affirming Blackness and Care for Black Lives}

J Blakeson's (2020) film I Care a Lot is about a power struggle between a white queer woman who is an executive con-artist, Marla Grayson (Rosamund Pike), and a white disabled man who is a Russian mobster, Roman Lunyov (Peter Dinklage). Grayson and Lunyov are in a battle over who will determine the fate of Lunyov's elderly mother. The film satirizes care as total corruption, using toxic white, bourgeois femininity to express a sinister and evasive form of domination. The premise of I Care a Lot assumes viewers will readily understand a connection between capitalism, state "weapons of mass care," and interrelated sites of power-courtrooms, older adult living facilities, and psychiatric institutions. After one of her "guardianship" victims dies, Marla Grayson complains that Alan Levitt, a man she is court-appointed to care for, was too young to die with at least five more years of life left to exploit. She needs another isolated and vulnerable "client" to add to her portfolio of victims, people healthy enough to survive overmedication and institutionalization. Surrounded by complicit enablers and a booming elder care industry, Grayson is fraudulently appointed legal guardian over Jennifer Peterson (Dianne Weist), a 71-year-old woman living under her son Lunyov's protection, using a fake name. Grayson has Peterson placed in a facility and begins selling her house and plundering her assets.

Under racial capitalism, white supremacist notions of goodness, protection, and care justify aggressive laws and a brutal economic system in order to make suffering profitable through the maintenance of harmful social conditions. Blakeson's movie barely glimpses what happens to people at the bottom of this system; the viewer should know that long-standing economic policies and legalized predatory practices have already filled training rooms with eager caregivers and protectors busy sustaining corporate empires. Watching this film, I (third author) was reminded that pathologizing and victimizing narratives of Blackness and disability have served to benefit helping professions, including the arts therapies, where white women, as the predominant practitioners in the field, can become empowered actors within racist institutions and systems. Coincidentally, these systems are embedded with fantasy narratives of white femininity, which have historically played a role in constructing anti-Blackness in the US, while shaping the institutions that "take care" of or "civilize" racialized others (Stoler, 1995; Ware, 1992). Meanwhile, the history, presence, and narratives of Black professionals, wage workers, and consumers in these systems are routinely dismissed. Lumpkin (2006) wrote:

One could say the dichotomy is one of being invisibly visible: being accepted but, on the other hand being constantly reminded of my Blackness and separate identity. As an assimilated college professor, I am invisible when colleagues only consider my value or request my input on issues pertinent to diversity or persons of color. (pp. 36-37)

At the height of racial justice uprisings in the U.S in 2020, visual narratives associating Blackness and prolonged suffering offered a protective buffer for mental health professions against a growing public critique of state violence (Gipson et al., 2020). Since it must be said that Black Lives Matter, it is also necessary to make other truths explicit. Black Lives Matter as a protest mantra gives voice to a Black queer feminist ethics of care and affective experiences of value. Black people-Black migrant communities, Black queer, trans, and gender non-conforming communities, Black disabled communities, Black girls and women, Black cis men-find care for Black lives even when ideologies of racism, patriarchy, and capitalism promise to neglect and destroy Black life.

Authors in this issue make critical contributions to ethics discourse in the arts therapies, providing framework analyses for practices of care in turbulent and hostile environments in education, professional development, and community mental health services. They insist upon practices of care in Black daily life and mourning, using storytelling, creative writing, autobiographical reflection, commentaries, and arts-based research. Although preference for non-literary texts is an accepted bias in mental 
health academic journals, we recognize how power operates, not only in the politics of citation, but in the exclusion of Black creative and spiritual practices of knowledge production. Arts therapies literature lacks evidence of deep listening and responses to Black lived experience partly as a result of these norms in the academy. The authors who address concepts of care in this issue use their chosen genres of writing, already existing within Black aesthetic oral and literary traditions and academic disciplines that value holistic and textured engagement with Black lifeworlds. We read their writings as a means of undoing white aesthetics as modes of professionalization that function to ignore and erase the historical displacement of Black arts therapists and Black communities.

Leah Gipson, Marisol Norris, Leah Amaral, Johanna Tesfaye, and Anna Hiscox pose the question, "What are you all going to do to keep Black women in art therapy?" as an assertion of Black women's agency to create safe and liberatory contexts for education. They begin with the significance of their collective participation in the 2018 Critical Pedagogy in the Arts Therapies Conference where Cliff Joseph spoke about the 1974 Art Therapy and the Third World panel (Joseph, 1974). The commentary offers a womanist manifesto for arts therapies education.

Leah Amaral and Johanna Tesfaye use a process of arts-based inquiry that embraces performance and sensory knowledge to address the politics of becoming an art therapist. In their creative essay, they describe a project based on a collective praxis of care and student activism during their time as art therapy graduate students. Reflecting on their experiences of Black personhood in professional and clinical spaces, Amaral and Tesfaye provide a range of emotional insights from co-creating BIPOC, sisterhood/sib spaces. They present their analysis using excerpts of poetry, dialogue, journal writing, and other documentary materials that were used to understand practices of community building.

Jasmine Edwards offers her experiences as a music therapist in the therapeutic performance Turbulence to describe the value of social identity affinity spaces and crossdisciplinary collaboration in the creative arts therapies that seriously grapple with race. She emphasizes placemaking, in particular supportive, culturally responsive, and justice-seeking environments, as vital to the professional development of BIPOC arts therapists. Relating personal meaning-making with relational dynamics that shaped her participation in the performance, Edwards cites the group's support within womanist ethics of care.

Rochele Royster explores the therapeutic benefits of craft culture activism using a liberation approach to art therapy in her research study on grief of trauma caused by gun violence. She focuses on the role of school- and community-based responses to the violence that impacts young people living in historically segregated Black neighborhoods in Chicago. Upsetting pathologizing narratives of Black people and the myth of Black on Black crime, Royster highlights how children in Chicago Public Schools led a collective living-memorial project to provide care and craft culture activism in their communities.

\section{Black Authorship Matters}

Whoever writes the story regulates who gets written in and also who/what gets erased. Whoever writes the story controls how the narrative is told and driven. Whoever writes the story governs what gets taken in. Hierarchical assumptions assert that where work is written underscores the inherent value of the piece. Merriam-Webster (n.d.) defines authorship as: "(1) the profession of writing (2) the source (such as the author) of a piece of writing, music, or art." The idea of authorship as inextricably tied to the written word is a notion steeped in and born from white supremacy. Black peoples have authored many ideas, theories, concepts, frameworks, creative works, and more that have been stolen, co-opted and expressed through the written word by white authors claiming the work as their own. Paradoxically, Black peoples' theories, practices, and works are dismissed by professional and academic institutions because the works sit- 
uate outside of white supremacist assumptions and expectations. For these reasons, spaces created by, with, and for Black authors are needed. I (second author) use the word author here in a disrupted sense; one wherein authorship is understood as expressed and communicated through multi-varied methods and modes. In this special issue, several Black authors explore, reveal, and disrupt notions of authorship; they have authored the stories they wish(ed) to read (Toni Morrison) and reflect.

In "Navigating US Citizenship and Colorism in the Dominican Republic: A Black Latinx Art Therapist's Experience," Johannil Napoleón addresses the need to decenter white narratives and experiences of power, privilege, and oppression. She notes that this predominant framing and understanding overshadows the needed discussion(s) regarding racial dynamics for BIPOC clinicians in the context of colorism.

In "Song as a Register for Black Feminist Theatre-Making Aesthetic," Refiloe Lepere asserts the need for writing that centers Black registers. Lepere cites song and poetics as a site for connection and expression among Black women. Furthermore, she highlights the erasure of song, poetics, and Black women's expressions in current understandings of knowledge production.

In "Tracks on Repeat: An Autoethnographic Poessay," Britton Williams weaves a narrative connecting the personal, professional, maintenance, and social-cultural. She notes the inextricable connectedness of these domains and the importance of restorying oppressive narratives that seek to remain elusive so that they may remain undone.

\section{Black Ownership \& Reclamation}

Ownership in this issue speaks as much to Black people's validity as creators as it does white people's legacies as pillagers, plunderers, overseers, masters, and lords. This assertion recognizes enslavement and colonialism as a central apparatus by which Black people are treated as property and their creations as material goods. This assertion also comes to bear the contemporary utility of ideological tools of dehumanization that circumvent Black personhood and seek to impose our physical, psychological, and spiritual bondage (Norris, 2020b). As such, talks about Black ownership within the arts therapies amplify the ways coloniality continues to transgress upon Black bodies and possession as a source of legitimacy and power (Norris, 2020a; Thomas \& Norris, 2021).

Black people are human beings, living subjects that hold personal and collective agency. We construct lifeworlds that index our ways of being and our active worldmaking. We have been subjected to theft-physical, epistemological, representational-and subjected to persistent attempts of dispossession. ${ }^{1}$ When Black lifeworlds are pillaged by non-Black people, they are often commodified as social power and professional economy intended to disproportionately benefit those in dominant positions. When Black people are plundered, their bodies are not their own. When Black people are overseen, they are subjected to the white colonial gaze and treated as property expected to act at will by threat of punishment. When Black people are mastered, their autonomy is subverted. When Black people are lorded by man, they are seen as extension-not self-possessed; they are solely expected to be vessels filled. When Black people's spirits are violently demonized only to be conjured and consumed, liberation must occur. White cultural dependence rests on a status of Black peoples as nonentity rather than the ability for white people to produce social heritage (Holland, 2000), self-control, labor, capital, and servitude. The delegitimization of Black people as knowers and creators serves to sustain white dominance and obfuscate white histories of physical, material, representational, and psychological violence. Black ownership as a political pursuit in the arts therapies centers the need to problematize the decontextualized histories of the arts therapies that have led to "vocational awe" - the set of ideas, values, and assumptions about a profession and the people within it that result in beliefs that sites of labor as "institutions are inherently good and sacred, and therefore beyond critique" (Ettarh, 2018, para. 3). This special issue centers the need to authorize the ownership and reclamation of ourselves. 
Recognizing problematic formulations of healing, recovery, and salvation within the arts therapies, we cannot help but reimagine and call upon multiple voices to reexamine ideas of possession. The writers of this special issue grapple with the complexities of Black people across multiple spheres. Collectively, they help to articulate the intellectual, epistemological, and representational forms that have long been appropriated by the arts therapies. Black notions of ownership articulated in this issue oppose colonial constructions of empire commonly noted in the arts therapies professions' neoliberal capitalist pursuits. They reinstate the authority and legitimacy of Black people as knowers and creators-the realization of their humanity.

In "How Do You Play When You're Prey? A Personal Exploration into Black Creative Healing," Natasha Thomas explores the collaborative world-making of the blog project "Black Creative Healing." Through personal analysis, Thomas asserts ownership of African and African diasporic healing legacies and their reclamation as a means of interrogation, resistance, and care. Similarly, kei slaughter, in "Run River," offers musical tribute to great great great great grandmother Nancy Maker Brown. slaughter evokes an ancestral memory that problematizes monolithic recounts of lineage and affirms the ownership of familial histories through sonic construction.

In an audio interview, Gipson and Norris discuss the origins of American musical traditions with singer, songwriter, and producer Adrian Dunn in "Black Lives Matter and The Black Messiah Album: An Interview with Adrian Dunn." Together they critique attempts to exorcise Blackness from popular musical productions and affirm the complexity of Black creativity as a source of radical healing. In the corresponding review, Kennedi Johnson explores the album The Black Messiah by Adrian Dunn and the Adrian Dunn Singers. Johnson contextualizes the "Hopera" within the wake of Black death, grief, and protest in the United States and situates its musical orchestration within a tradition of liberatory struggle.

Rodney Simpson Jr., in "The Butterfly Blues," stories the hostility of a cis-heteronormative world and the spiritual journey of owning his identity as a Black queer man. Simpson reveals the tensions of faith and embodiment through multimodal artistic expressions. Last but not least, esperanza spalding, in "Black Aesthetic/s as Divine Lover of No End In Sight: The Progenitors of World Altering Resiliency," provides rhythmic prose that centers Black aesthetic world-making. spalding's provocations call for the recognition of Black life and life-force as restorative, sensuous, and spiritual offerings. As such, spalding considers Black aesthetical alchemy as a progenitor of place, creation, ownership, and reclamation and an Afrofuturist path to liberation and healing.

\section{Arts Therapies in Need of Critical Genealogies}

This special issue honors the broad spectrum of symbolic discourse needed to understand the relationship between values and enacted violence. Readers will notice that the issue is comprised of fewer research articles in the overall project, which we believe speaks to structural inequities of time and resources for Black arts therapists, especially during the COVID-19 pandemic, as well as the politics and scholarly preferences of each writer. This issue, in its unconventional collective of knowledge, enters into a dialogue with Black aesthetic traditions; we know that Black arts therapies practitioners and scholars have always used African and African diasporic epistemologies to delegitimize the influences of patriarchy, colonization, and racial capitalism on how we be, and how we do. Black aesthetics and ethics of care must be integrated into a broader understanding of the field of the arts therapies. As co-editors of this issue, we aim to undo paradigms of enacted violence caused by devaluing and co-opting the creative intellectual labor and leadership of Black peoples, and to move toward critical genealogies in and beyond the field. We bring a critical awareness that Black consumers of arts therapies services are negatively impacted by the retelling of their experiences in professional literature largely without the field's awareness or radical engagement with Black aesthetics. We are also aware of our positioning ${ }^{3}$ as Black women who are publishing in a mainstream academic journal and working within and around estab- 
lished conventions, including our individual decisions about participation in or refusal of mainstream professional organizations and institutions that have presented barriers for Black arts therapists and people of color before us. Our elicitation of Black Lives Matter strives toward uncanonizing the arts therapies and dares to reimagine critical genealogies that build therapeutic, emancipatory, and transdisciplinary pathways between Africana studies, Black feminist studies, and the arts therapies. Envisioning these connections, for example, I (third author) place BIPOC arts therapists' critiques of a dominant gaze through the histories of the professions in a possible dialogue with the contexts that produced Sojourner Truth's 1864 carte-de-visites, Machado de Assis's (1871) short story "Mariana," Sarah Mapps Douglass's 1836-37 paintings in the Friendship Albums and her women's health (anatomy) lessons with Black girls, or the foundational epistemologies of community psychotherapy existing between George Seabrooke Powell's post-Harlem Renaissance public art practice, Franz Fanon's revolutionary psychiatry, and Camille Billops's early studies in art and occupational therapy. Introducing these critical genealogies have the potential to upset anti-Black aesthetics within the arts therapies' clinical gaze.

\section{Reimagining}

In such a case, we offer these words and prose in alignment to the central question we seek to unearth: What does it mean to upset, undo, and uncanonize our field?

Leah: I am not asking whether we should be here, but how we will remain and be reminded of our wholeness in every place of our being. Gift Black selves the permission to describe what is present even if no one else in the room sees it. Topple that mess over and the earth quakes and soothes our spirits.

Marisol: It also means tending to our senses-our thick interior knowledge as "theory in the flesh"- that contribute to the long legacies of active world-making within the African diaspora (Moraga \& Anzaldúa, 2015, p.19). It means connecting our senses to our creative potentials, our ability to transform our being and create new possibilities for our work and communities. The demands to deny that which is felt, what is sensed, what is already known are acts of violence, an offense in itself that aims to render Black therapists and healers incapable of the healing work within their capacity. To vision our work anew is to return to what is known and a commitment to what is yet known as a means of collective healing.

Britton: I love moments of Black acknowledgement. It's that: I don't know you and you don't me... but we know each other. It's in that nod as we pass by each other. It's the smile that says, "I'm glad you're here." I appreciate moments of Black relational knowing. It's in that look that holds a whole conversation and requires not one word. It's in that facial expression that says, "Yeah, I saw that too." It's that unspoken but strongly felt knowing that I got you and you got me too. Black music... making it and engaging it with my people is full-bodied joy... it is soul healing. And all of this is ancestral... it is knowledge passed down... it is knowledge passed through...

\section{About the Editors}

Marisol Norris, PhD, is a music therapist, critical arts therapies educator, cultural worker, and founder of the Black Music Therapy Network, Inc. Her music therapy practice and supervisory experience have spanned medical and community health settings and include music therapy with adolescents experiencing housing insecurity, adults with psychiatric and dual diagnoses, families within the city court system and medically fragile children. These experiences have profoundly contributed to her multicultural relational lens and her dedication to fostering culturally sustaining, liberatory frameworks in music therapy education and practice. Her teaching and cultural work is an extension of a broader commitment to healing justice and dismantling relational and structural violence through community-based advocacy, education, and action.

Britton Williams is a Black woman. Drama Therapist. A myriad of hyphens and ands. She is a teacher and student. A thinker and dreamer. She is urgently concerned with 
the possibilities that live with/in radical (re)imagining and the inextricable connectedness of healing and liberation. And ...

Leah Gipson is Assistant Professor in the Art Therapy and Counseling Department at the School of the Art Institute of Chicago (SAIC). She is a registered and board-certified art therapist (ATR-BC), and a licensed clinical professional counselor (LCPC) in Illinois, with a Master of Theological Studies. Leah is a board member for A Long Walk Home, an organization that uses the arts to empower young people to end violence against girls and women. She is also a board member of Praxis, an organization that provides affordable, democratically managed housing to individuals and families involved in social justice movement building. She is a co-founder of the BIPOC Student Fund by Black Arts Therapy Educators and an organizing member of the Critical Pedagogy in the Arts Therapies Alliance, formed in 2018.

\section{Notes}

1. I (first author) use the word dispossession in two forms: (a) as an act of dislocating Black people from their physical land and sense of place, as persistently enacted with Indigenous peoples through violent means, and (b) as an act of depriving Black people of their autonomy, legacies, and genealogies. Both forms can be subjected to ideologies that create the meaning of what it is "to possess" and "be possessed." Within this section, creative license is used to consider possession broadly, in all forms, recognizing that ideologies "do their jobs when they help insiders make sense of the things they do and see-ritually, repetitively-on a daily basis" (Fields \& Fields, 2014, p. 135).

2. Term originally used by Ettarh (2018) to describe librarianship.

3. As co-editors, we also discussed the need for dialogue and transparency about conventions of co-editorial authorship order and the problems with determining contribution without considering how the unpaid labor of Black women in the academy is negotiated according to part-time or full-time academic position and non-tenured status.

\section{References}

Avilez, G. S. (2017). Radical aesthetics and modern Black nationalism. University of Illinois Press.

Bewaji, J. A. I. (2012). Black aesthetics: An introduction to African and African diaspora philosophy of arts. Africa Research \& Publications.

Blakeson, J. Director. (2020). I care a lot [Film]. Black Bear Pictures, Crimple Beck.

Center for Disease Control. (2021a). Demographic trends of COVID-19 cases and deaths in the US reported to CDC. https://covid.cdc.gov/covid-data-tracker/\#demographics.

Center for Disease Control. (2021b). Risk for COVID-19 infection, hospitalization, and death by race/ethnicity. https://www.cdc.gov/coronavirus/2019-ncov/covid-data/investigationsdiscovery/hospitalization-death-by-race-ethnicity.html.

Coates , T. (2015). Between the world and me. Spiegel \& Grau.

Crawley, A. T. (2017). Blackpentecostal breath: The aesthetics of possibility. Fordham University Press.

DuBois Shaw, G. (2004). Seeing the unspeakable: The art of Kara Walker. Duke University Press.

Ettarh, F. (2018, January 1). Vocational awe and librarianship: The lies we tell ourselves. In the library with the lead pipe. http://www.inthelibrarywiththeleadpipe.org/2018/vocationalawe/

Fields, K. E., \& Fields, B. J. (2014). Racecraft: The soul of inequality in American life. Verso Books.

Gipson, L., Williams, B., \& Norris, M. (2020). Three Black women's reflections on COVID-19 and creative arts therapies. Voices: A World Forum for Music Therapy, 20(2), https://doi.org/ 10.15845/voices.v20i2.3115. 
Holland, S. P. (2000). Raising the dead: Readings of death and (Black) subjectivity. Duke University Press Books.

Joseph, C. (1974). Art therapy and the third world: A panel discussion presented at the 5th Annual Convention of the American Art Therapy Association [Monograph].

Lumpkin, C. L. (2006). Relating cultural identity and identity as art therapist. Art Therapy: Journal of the American Art Therapy Association, 23(1), 34-38, https://doi.org/10.1080/ 07421656.2006.10129529.

Merriam-Webster. (n.d.). Merriam-Webster.com dictionary. Retrieved February 5, 2021, from https://www.merriam-webster.com/dictionary/authorship

Moraga, C., \& Anzaldúa, G. (2015). This bridge called my back: Writings by radical women of color. State University of New York Press.

Moten, F. (2003). In the break: The aesthetics of Black radical tradition. University of Minnesota Press.

Neal, L. (1968). The Black arts movement. Drama Review, 12(4), 29-39.

Norris, M. (2020a). A call for radical imagining: Exploring anti-Blackness in the music therapy profession. Voices: A World Forum for Music Therapy, 20(3), https://doi.org/10.15845/ voices.v20i3.3167.

Norris, M. (2020b). Freedom dreams: What must die in music therapy to preserve human dignity? Voices: A World Forum for Music Therapy, 20(3), https://doi.org/10.15845/ voices.v20i3.3172.

Rabelo, V. C., Robotham, K. J., \& Mccluney, C. L. (2020). “Against a sharp white background”: How Black women experience the white gaze at work. Gender, Work \& Organization, https://doi.org/10.1111/gwao.12564.

Sharpe, C. (2016). In the wake: On Blackness and being. Duke University Press.

Stepney, S. (2019). Visionary architects of color in art therapy: Georgette Powell, Cliff Joseph, Lucille Venture, and Charles Anderson. Art Therapy: Journal of the American Art Therapy Association, 3(3), 115-121, https://doi.org/10.1080/07421656.2019.1649545.

Stoler, A. L. (1995). Race and the education of desire: Foucault's history of sexuality and the colonial order of things. Duke University Press.

Taylor, P. C. (2016). Black is beautiful: A philosophy of Black aesthetics. Wiley-Blackwell.

Thomas, N., \& Norris, M. (2021). "Who you mean “we'?”: Confronting professional notions of belonging in music therapy. Journal of Music Therapy, 58(1), 5-11, https://doi.org/ $10.1093 / \mathrm{jmt} /$ thaa024.

Ware, V. (1992). Beyond the pale: White women, racism and history. Verso.

Welsh-Asante, K. (1994). The African aesthetic: Keeper of the traditions. Praeger.

Yancy, G. (2013, September 1). Walking while Black in the 'white gaze'. The New York Times. https://opinionator.blogs.nytimes.com/2013/09/01/walking-while-black-in-the-whitegaze/ 